\title{
Effect of different Humic Acids Sources on the Plant Growth, Cal- cium and Iron Utilization by Sorghum
}

\author{
M. M. Hamad and Manal F. A. Tantawy* \\ Soils, Water and Environment Research Institute, Agriculture Research Center, Giza, Egypt
}

\begin{abstract}
$\mathbf{H}$ umic acids are widely used in agriculture system for high quality plant production, but are these different source acids equally efficient. So, a pot experiment was carried out during two successive summer seasons (2016 and 2017) to study the effect of both individual and combined applications of different three sources of humic acids and either of $\mathrm{Ca}$ or $\mathrm{Fe}$ on growth and $\mathrm{Ca}$ and $\mathrm{Fe}$ utilization by sorghum plants, variety Giza 15, under sandy culture condition. Three humic acids isolated from different sources, i.e., clayey soil (HAS); podrite (HAP) and compost (HAC) were used. Each HA was applied at rates of 0, 25, 50, 75 and $100 \mathrm{mg} \mathrm{kg}^{-1}$ refined sand. Either of $\mathrm{Ca}$ or $\mathrm{Fe}$ was added as acetate form $\left(\mathrm{CH}_{3} \mathrm{COO}\right)$ at rates of $0,25,50$ and $100 \mathrm{mg} \mathrm{kg}^{-1}$ refined sand. The experimental design was a split-split plot design with three replicates. Results showed that, applications of each three HA individually and in combination with $\mathrm{Ca}$ or $\mathrm{Fe}$ were associated by a significant increases of dry weights of shoots and roots of sorghum plants. The highest dry weights were found in the plants treated by HAC followed by those associated the treatments of HAP. So according the calculated RI (\%) values for the mean treatments of different added Ca rates, the estimated dry matter yields of shoots and roots may be arranged as follows: HAC (137.0 and $179.1 \%)>$ HAP $(98.84$ and $143.0 \%)>$ HAS (98.04 and $84.31 \%$ ) respectively. While, the corresponding order with different addition of Fe rates were HAC (114.4 and $217.9 \%)>\operatorname{HAP}(108.8$ and $148.2 \%)>\operatorname{HAS}(101.1$ and $76.99 \%)$ for shoots and roots dry matter yields, respectively. In addition, increasing application rates of $\mathrm{HA}$ and $\mathrm{Ca}$ or Fe were associated with increases of $\mathrm{Ca}$ and $\mathrm{Fe}$ uptake by both shoots and roots. The found order of the used HA on the increase of $\mathrm{Ca}$ and $\mathrm{Fe}$ uptake by shoots and roots of sorghum plants was: HAC $>\mathrm{HAP}>\mathrm{HAS}$. Moreover, the uptake of $\mathrm{Ca}$ and $\mathrm{Fe}$ by shoots was higher than that uptake by roots. On the other hand, increasing application rates of $\mathrm{Ca}$ and $\mathrm{Fe}$ decreased their utilization rate by sorghum plants. While, increasing application rates of HA were associated by an increase in the utilization rate of $\mathrm{Ca}$ and $\mathrm{Fe}$ by sorghum plants. Based on the obtained data, may be concluded that the fertilization program of sorghum plants must be include applications of $\mathrm{HA}$ especially $\mathrm{HAC}$ with $\mathrm{Ca}$ and $\mathrm{Fe}$ to obtained high quantity and quality of sorghum plants. Also, organic amendments must be used to increase Ca and Fe fertilizers efficiency.
\end{abstract}

Key words: Humic acids, Calcium, Iron, Nutrient uptake, Nutrient utilization rate, Sorghum plants

\section{Introduction}

Humic acids are a commercial product contains many nutrients which improve the soil fertility and increasing the phyto-availability of nutrients and consequently affected plant growth and yield. Humic acids particularly is used to remove or decrease the negative effects of mineral fertilizers and some chemicals forms in the soil. So, humic substances have many beneficial effects on soil and consequently on plant growth and are shown highly hormonal activity. These materials not only increase macronutrients contents and ions uptake but also enhance micronutrients of the plant organs (Brunetti et al. 2005 ). In addition, Montaser et al. (2011) reported that the humic acids (HA) may increase the permeability of plant membranes and enhance the uptake of 
nutrients. Moreover, HA may also improve soil nitrogen uptake and facilitate the uptake of potassium, calcium, magnesium and phosphorus, making these nutrients more mobile and available to plant root systems. Also, humic substances are organic substances of high molecular weights, and they are naturally widespread in aquatic and terrestrial environments. Iron-reducing bacteria can substitute humic substances for Fe(III) as the terminal electron acceptor. The ecological significance of humic acid reduction in natural environments is not well understood (Kappler et al. 2004). A further understanding of the relation between humic substance reduction and iron is important and requires knowledge about the diversity of microbes that might be responsible for this reduction in sedimentary environments.

Calcium is one of an essential macronutrients; however, its role is elusive. When examining total $\mathrm{Ca}$ in plants, the concentration is quite large $(\mathrm{mM})$, but its requirement is that of a micronutrient $(\mu \mathrm{M})$. Calcium is not usually limiting in field conditions, still there are several defects that can be associated with low levels of this ion, including poor root development, leaf necrosis and curling, blossom end rot, bitter pit, fruit cracking, poor fruit storage, and water soaking. The underlying causes for these effects are not entirely clear; nevertheless, two areas within the cell have been recognized as being important targets. First is the cell wall, where $\mathrm{Ca}$ plays a key role in cross-linking acidic pectin residues. The second is the cellular membrane system, where low $\mathrm{Ca}$ increases the permeability of the plasma membrane (Hepler, 2005).

Also, iron $(\mathrm{Fe})$ is one of an essential micronutrients for plants. In this concern, Marschner (2012) reported that $\mathrm{Fe}$ is most important for the respiration and photosynthesis processes. Iron is also implied in many enzymatic systems like chlorophyll synthesis. The mobility of iron in the plant is very low. Therefore, the species of Fe in the soil environment could be summarized in the following: (1) $\mathrm{Fe}^{\mathrm{II}}$ in primary minerals; (2) $\mathrm{Fe}^{\mathrm{III}}$ in secondary minerals, as Fe crystalline minerals and poorly ordered crystalline (hydro) oxides; (3) soluble and exchangeable Fe; and (4) Fe bound to organic matter in soluble or insoluble forms. In addition, iron mobilization was influenced by the complexation of iron to soluble inorganic ligands through iron-binding molecules of low molecular weight called siderophores, which are

Egypt. J. Soil. Sci. 58, No. 3 (2018) released from microbes (Lemanceau et al. 2009) or phytosiderophores which are released from graminaceous plant species (Awad et al., 1988 and Awad et al. 1994). This process also causes iron to be removed not only from iron minerals but also from organic complexes such as organic acids, phenols, and soil humic substance ligands (Colombo et al. 2014).

Sorghum Vulgare var saccharatum, of family Gramineae, commonly called sorghum and also known as great millet, durra, jowari, or milo, is a grass species cultivated for its grain, which is used for food, both for animals and humans, and for ethanol production. Sorghum originated in northern Africa, and is now cultivated widely in tropical and subtropical regions. Sorghum is the world's fifth most important cereal crop after wheat, rice, maize and barley. Sorghum has a variety of uses including food for human consumption, feed grain for livestock and industrial applications such as ethanol production (Delserone, 2008). Also, FAO (2012) showed that, the area planted to sorghum worldwide has increased by 66 percent over the past 50 years while yield has increased by 244 percent. The leading producers of sorghum bicolor in 2011 were Nigeria $(12.6 \%)$, India (11.2\%), Mexico (11.2\%) and the United States (10.0\%). Sorghum grows in a wide range of temperature, high altitudes, toxic soils and can recover growth after some drought. It has four features that make it one of the most droughtresistant crops:

It has a very large root-to-leaf surface area ratio.

In times of drought, it will roll its leaves to lessen water loss by transpiration.

If drought continues, it will go into dormancy rather than dying.

Its leaves are protected by a waxy cuticle.

Thereafter, this pot experiment was carried out using sandy culture to study the effect of both individual and combined applications of different sources and rates of humic acids and either of $\mathrm{Ca}$ or Fe on sorghum plants growth and its chemical composition. Also, the role of humic acids on $\mathrm{Ca}$ and $\mathrm{Fe}$ utilization by sorghum plants was assessment. 


\section{$\underline{\text { Materials and Methods }}$}

This study was carried out using sandy culture as a pot experiment in greenhouse at the Experimental Farm of Soils, Water and Environment Res. Inst., Agric. Res. Center, Giza, Egypt with sorghum plants (Sorghum Vulgare var saccharatum), variety Giza 15 as a test plant during two successive growth summer seasons of 2016 and 2017 to study the effect of both individual and combined applications of different three sources of humic acids and either of $\mathrm{Ca}$ or $\mathrm{Fe}$ at different application rates on sorghum plants growth and its some chemical composition. Also, the role of humic acids on $\mathrm{Ca}$ and $\mathrm{Fe}$ utilization by sorghum plants was assessment. Each humic acid was applied at rates of $0,25,50,75$ and $100 \mathrm{mg}$ $\mathrm{kg}^{-1}$ sand. Either of $\mathrm{Ca}$ or $\mathrm{Fe}$ was added as acetate form $\left(\mathrm{CH}_{3} \mathrm{COO}\right)$ and at rates of $0,25,50$ and 100 $\mathrm{mg} \mathrm{kg}{ }^{-1}$ sand.

\section{Humic acids preparation}

In this study, three humic acids isolated from different sources were used. The first humic acid (HAS) used in this study was extracted from the clayey soil of Experimental Farm of the Soils, Water and Environment Res. Inst., Agric. Res. Center, Giza, Egypt; the second humic acid (HAP) was isolated from podrite and the third one (HAC) was extracted from compost of clover straw, where each acid was applied at rates of $0,25,50$, 75 and $100 \mathrm{mg} \mathrm{kg}^{-1}$ sand. These humic acids were extracted, fractionated and purified according to the methods described by Kononova (1966); Posner(1966); Chen et al. (1978) and Schnitzer and Khan (1978). The purified humic acids content of $\mathrm{C}, \mathrm{N}, \mathrm{P}$ and $\mathrm{H}$ was determined according to Mann and Sounders (1966); Bremmes and Mulvaney (1982) and Olsen and Sommers (1982). Humic acids content of oxygen $(\mathrm{O})$ was calculated by subtracting the content $\left(\mathrm{g} \mathrm{kg}^{-1}\right)$ of C, N, P, H, Ca and $\mathrm{Fe}$ from the total of 1000 . Ash content (\%) of these humic acids was estimated by burning the oven dry humic acid at $750{ }^{\circ} \mathrm{C}$ for $24 \mathrm{hr}$ ( Holder and Griffith, 1983 ). The obtained results of the total nutrients and the calculated atomic ratios for the three humic acids arre recorded in Table 1. Also, the studied humic acids contents of total acidity and some functional groups, i.e. carboxyl $(\mathrm{COOH})$, total-OH, phenolic-OH and alcoholic $-\mathrm{OH}$ were determined according to the methods described by Dragunova (1958); Kukhareko (1937) and Brooks et al. (1958) and the obtained data are recorded in Table 2.

\section{Sandy culture preparation}

Sand used in this study was taken from desert part of Quessna region, Minufia Governorate. Sand was sieved through a $2 \mathrm{~mm}$ sieve, washed by tap water, treated with diluted $\mathrm{HCl}(6 \%)$ and $\mathrm{H}_{2} \mathrm{O}_{2}(30 \%)$ to remove the carbonate and oxidize the organic matter, respectively. The treated sand was washed several times with tap water followed by distilled water up to the sand become free from $\mathrm{Cl}$. The refined sand was air-dried kept for using.

\section{Nutrient solution}

The pots were irrigated every two days in the using nutrient solution alternated with tap water at the moisture content of $60 \%$ of water holding capacity. The composition of the complete essential nutrient (normal) solution was: $4 \mathrm{mM} \mathrm{KNO}_{3}$, $4 \mathrm{mM} \mathrm{Ca}\left(\mathrm{NO}_{3}\right)_{2}, 2 \mathrm{mM} \mathrm{MgSO}{ }_{4}, 1.33 \mathrm{mM} \mathrm{NaH}-$ ${ }_{2} \mathrm{PO}_{4}, 100 \mu \mathrm{M}$ Fe-EDTA, $10 \mu \mathrm{M} \mathrm{MnSO}_{4}, 30 \mu \mathrm{M}$ $\mathrm{H}_{3} \mathrm{BO}_{3}, 1 \mu \mathrm{M} \mathrm{ZnSO}_{4}, 0.2 \mu \mathrm{M} \mathrm{Na}_{2} \mathrm{MoO}_{4}, 0.1 \mu \mathrm{M}$ $\mathrm{CoSO}_{4}, 0.1 \mu \mathrm{M} \mathrm{NiSO}_{4}$ and $0.1 \mathrm{mM} \mathrm{NaCl}$ (Agarwala and Chatterjee 1996).

\section{Pot experiment}

A 360 plastic pots with $25 \mathrm{~cm}$ inter diameter and $20 \mathrm{~cm}$ depth were used in this study. Each pot was filled by $3 \mathrm{~kg}$ of refined and air-dried sand (sandy culture). Each pot was cultivated by 8 grains of sorghum, the rates of seeds cultivated were taken from Egyptian Ministry of Agriculture recommendations. In 17 May 2016 and 2017, the cultivated pots were irrigated using tap water at $60 \%$ of water holding capacity. The layout of the experiment was a split - split - plot design, with the main plots arranged in a randomize complete block design, with three replicates. After 10 days of planting, the plants of each pot were thinned at 5 plants. After thinning directly, the pots were divided into three main groups (120 pot/main group ) representing the main factor or humic acids ( HAS ; HAP and HAC ) treatments. The pots of each main group were divided into equal five sub groups (24 pot for each sub group) which treated by one application rate of humic acid $(0,25,50$, 75 and $100 \mathrm{mg} \mathrm{kg}^{-1}$ refined sand ). At the same time, the pots of each subgroup were divided into two sub sub groups ( 12 pot / sub sub group ) representing the treatment of $\mathrm{Ca}$ and $\mathrm{Fe}$. The pots of each sub sub group were divided into equal four groups ( 3 pot for each group ), where the pots of each final group were treated by one concentration of $\mathrm{Ca}$ or $\mathrm{Fe}$. Both $\mathrm{Ca}$ and $\mathrm{Fe}$ was added as acetate form $\left(\mathrm{CH}_{3} \mathrm{COO}\right)$ and at rates of $0,25,50$ and 100 $\mathrm{mg} \mathrm{kg}^{-1}$ refined sand with irrigation water. 
TABLE 1. Chemical analysis of the studied three humic acids

\begin{tabular}{|c|c|c|c|c|c|c|c|c|c|c|c|c|}
\hline \multirow{2}{*}{$\begin{array}{l}\text { Humic } \\
\text { acids }\end{array}$} & \multicolumn{7}{|c|}{ Total nutrients $\left(\mathrm{g} \mathrm{kg}^{-1}\right)$} & \multicolumn{5}{|c|}{ Atomic ratios } \\
\hline & $\mathbf{C}$ & $\mathbf{H}$ & $\mathbf{N}$ & $\mathbf{P}$ & $\mathbf{O}$ & $\mathrm{Ca}$ & $\begin{array}{c}\mathrm{Fe} \\
\left(\mathrm{mg} \mathrm{kg}^{-1}\right)\end{array}$ & $\mathbf{C} / \mathbf{H}$ & $\mathrm{C} / \mathrm{O}$ & $\mathbf{C} / \mathbf{N}$ & $\mathbf{C} / \mathbf{P}$ & $(\%)$ \\
\hline HAS & 465.4 & 61.5 & 22.5 & 8.5 & 430.4 & 11.4 & 298 & 7.57 & 1.08 & 20.7 & 54.8 & 1.85 \\
\hline HAP & 451.8 & 55.0 & 29.8 & 6.8 & 441.8 & 14.5 & 335 & 8.21 & 1.02 & 15.2 & 66.4 & 2.25 \\
\hline $\mathrm{HAC}$ & 438.5 & 52.8 & 27.0 & 6.3 & 462.8 & 12.2 & 421 & 8.30 & 0.95 & 16.2 & 69.6 & 1.70 \\
\hline
\end{tabular}

TABLE 2. Total acidity and some functional groups ( meq $\left.100 \mathrm{~g}^{-1} \mathrm{HA}\right)$ of the three studied humic acids

\begin{tabular}{cccccc}
\hline Humic acids & Total acidity & COOH & Total - OH & Phenolic - OH & Alcoholic - OH \\
\hline HAS & 580.4 & 270.1 & 445.8 & 310.3 & 135.5 \\
HAP & 630.8 & 305.4 & 505.6 & 350.4 & 150.2 \\
HAC & 710.50 & 330.4 & 527.6 & 380.1 & 182.5 \\
\hline
\end{tabular}

Preparation and analyses of plant samples

At the end of the two seasons (after 65 days of planting), the plants of each treatment were harvested separately from each pot as a whole and separated into shoots and roots. Both shoots and roots of each sample were washed with tap-water and then 2 times with distilled water, air- dried, oven-dried at $70{ }^{\circ} \mathrm{C}$ for 48 hours until weight becomes constant and weighted to record the dry weights $\left(\mathrm{g} \mathrm{pot}^{-1}\right)$. The plant samples were ground separately to a fine powder in a stainless grinder and stored in plastic bags until analysis. Half $g$ portions of each dried plant sample was digested by a concentrated mixture of $\mathrm{H}_{2} \mathrm{SO}_{4}+\mathrm{HClO}_{4}$ at ( $5: 0.5$ ) ratio according to Chapman and Pratt (1961). The content of both Ca and Fe was determined in the find plant digests. The calcium was determined by titration method with EDTA standard solution and ammonium perpurity as indicator according to Cottenie et al. (1982). Also, iron content was measured using Perkin Elmer atomic absorption, spectrophotometer model 2830.
The assessment of the studied parameters

Relative increase percentage (RI) of the obtained dry matter yields of sorghum plants (shoots and roots) as affected by the studied treatments was calculated by the following equation:-

$\mathrm{RI}=[($ dry matter yield of treated plants - dry matter yield of untreated plants)/ dry matter yield of untreated plants $] \times 100$

The utilization rate for $\mathrm{Ca}$ and $\mathrm{Fe}$ application by shoots and roots of sorghum plants were fertilized by different three sources of humic acids may be calculated using the following equation:

$\mathrm{SU}=\left[\left(\mathrm{PS}_{\mathrm{T}}-\mathrm{PS}_{\mathrm{O}}\right) / \mathrm{S}_{\mathrm{T}}\right] \times 100$ (Fouda et al. 2013). where : $\mathrm{SU}(\%)=\mathrm{Ca}$ or $\mathrm{Fe}$ utilization rate.

$\mathrm{PS}_{\mathrm{T}}=\mathrm{Ca}$ or Fe uptake $\left(\mathrm{mg} \mathrm{pot}^{-1}\right)$ by treated plants at different application rates. 
$\mathrm{PS}_{\mathrm{O}}=\mathrm{Ca}$ or Fe uptake $\left(\mathrm{mg} \mathrm{pot}^{-1}\right)$ by untreated plants with $\mathrm{Ca}$ or Fe.

\section{$\mathrm{S}_{\mathrm{T}}=$ Application rate $\left(\mathrm{mg} \mathrm{kg}^{-1}\right)$ of $\mathrm{Ca}$ or Fe.}

The data were exposed to statistical analysis according to Gomez and Gomez (1984). The significant differences among means were tested using the least significant differences (L.S.D.) at 5 $\%$ level of significant error.

\section{Results and Discussion}

Effect of different sources and rates of humic acids and four application rates of $\mathrm{Ca}$ and $\mathrm{Fe}$ on:

Dry matter yield of sorghum plants

Data in Tables 3 to 6 and Fig. 1 to 4 show, the dry matter yield (g pot-1) of sorghum plants (shoots and roots) and their relative increases (RI, $\%)$. Increasing rates of added humic acids were associated by a significant increases of both roots and shoots dry matter yield under different application rates of $\mathrm{Ca}$ and $\mathrm{Fe}$. The found increases in dry matter yield of sorghum as a result of humic acids applications widely varied according to the added humic acid resource. According to the found dry matter yield and their relative increase $(\mathrm{RI}, \%)$ in the plants treated only with humic acids, the used humic acids takes the order: HAC $=$ HAP $>$ HAS for shoots and was HAC $>$ HAP $>$ HAS for roots (based on the mean values of the used humic acids applications in the two growing seasons). This order was cleared from the calculated values of relative increases (RI) of dry matter yields of sorghum (shoots and roots) plants as a results of humic acids application, where the highest positive values of RI (\%) were found in the plants treated with HAC followed by these found in the plants treated with HAP. These increase of sorghum (shoots and roots) dry matter yield mainly resulted from many essential macroand micronutrients presented in the used humic acids (Tables, 1 and 2) and also to their effect on improving growth media. The same significant increase effect of humic acid applications on the dry matter yield was reported by many investigators such as Morard et al. (2011) on various plant species; Mohamed (2012) on maize; Nada and Tantawy (2012) on tomato and Abd El-Kader (2016) on wheat. With all individual treatments of humic acids, the dry matter yields (g pot-1) for shoots were higher than those of roots (Tables 3 to 6).
Data in Tables $3 \& 4$ and Fig. $1 \& 2$ show, the effect of individual applications of Ca on dry matter yield of sorghum (shoots and roots) plants and their relative increase (RI, \%). The dry matter yields of both shoots and roots increased significantly with the increase rate of added $\mathrm{Ca}$, so RI (\%) values were increased and become more positive at high rates of added $\mathrm{Ca}$. For example RI increased from $37.68 \%$ at rate of $25 \mathrm{mg} \mathrm{Ca} \mathrm{kg}-1$ to $105.71 \%$ at rate of $100 \mathrm{mg} \mathrm{Ca} \mathrm{kg-1}$ for shoots dry matter yield and increased from $10.30 \%$ to 68.91 $\%$ with the increase of added $\mathrm{Ca}$ from 25 to 100 mg kg-1 for roots dry matter yield. Also, data in the same table showed that, at the same application rate of $\mathrm{Ca}$, the dry matter yield of shoots was higher than that of roots. The significant increase effect of $\mathrm{Ca}$ on plant growth resulted from crosslinking acidic pectin residues. Also, $\mathrm{Ca}$ is the cellular membrane system, where low it increases the permeability of the plasma membrane ( $\mathrm{He}$ pler, 2005 and Marschner, 2012). In this respect Tuna et al. (2007) and Mohamed (2012) obtained on similar results.

In addition, combined applications of both humic acids (HAS, HAP and HAC) and $\mathrm{Ca}$ at different rates resulted in a significant increases of sorghum (shoots and roots) plants dry matter yield (g pot-1) compared with their individual applications (Tables, 3 and 4). These findings may be cleared and supported by calculated RI (\%) values, where these values were increased with the increase rate of added humic acids and $\mathrm{Ca}$. The found increases of dry matter yields of sorghum plants as a result of humic acids and $\mathrm{Ca}$ application together resulted from their effect on plant growth by increasing enzymes activity and metabolic processes and also to improve growth media conditions as premeditation by many investigators (Nardi et al., 2002; Marschner, 2012 and Mohamed, 2012). In all combined treatments of humic acids and calcium, dry matter yields of shoots were higher than those roots. At the same treatment of humic acid and $\mathrm{Ca}$, RI (\%) of shoots dry matter yield was higher than that of roots. This trend means that, shoots of sorghum plants appeared high response to different applications of humic acids and $\mathrm{Ca}$ higher than that found with the roots. Within the combined treatments of humic acids and $\mathrm{Ca}$ there are clear variations in the obtained dry matter yields of both shoots and roots affected by the source of added humic acid, where the highest yields and relative increase were found in the plants treated by HAC and the lowest values were found in the plants treated by HAS. This trend showed the clear effect of humic acid chemical composition on plant growth (Thah et al., 2006; Hussein \& Hassan, 2011 and Turan et al., 2011). 
TABLE 3. Dry matter yield of shoots and roots $\left(\mathrm{g} \mathrm{pot}^{-1}\right)$ of sorghum as affected by different sources and rates of humic acids under four application rates of $\mathrm{Ca}$ (mean values two seasons)

\begin{tabular}{|c|c|c|c|c|c|c|c|c|c|c|c|}
\hline $\begin{array}{l}\text { Humic } \\
\text { acids } \\
\text { treat- } \\
\text { ments }\end{array}$ & & \multicolumn{5}{|c|}{ Shoots } & \multicolumn{5}{|c|}{ Roots } \\
\hline & \multicolumn{5}{|c|}{ Added Ca rate $\left(\mathrm{mg} \mathrm{kg}^{-1}\right)$} & \multicolumn{5}{|c|}{ Added Ca rate $\left(\mathrm{mg} \mathrm{kg}^{-1}\right)$} & \multirow[b]{2}{*}{ Mean } \\
\hline Source & $\begin{array}{c}\text { Rate } \\
\left(\mathrm{mg} \mathrm{kg}^{-1}\right)\end{array}$ & 0 & 25 & 50 & 100 & Mean & 0 & 25 & 50 & 100 & \\
\hline \multirow{6}{*}{ HAS } & 0 & 1.733 & 2.386 & 2.919 & 3.565 & 2.651 & 1.039 & 1.146 & 1.286 & 1.755 & 1.307 \\
\hline & 25 & 1.930 & 2.690 & 3.235 & 4.154 & 3.002 & 1.068 & 1.460 & 1.470 & 1.972 & 1.493 \\
\hline & 50 & 2.038 & 2.900 & 3.590 & 4.654 & 3.296 & 1.148 & 1.746 & 1.972 & 2.105 & 1.743 \\
\hline & 75 & 2.183 & 3.283 & 4.669 & 5.632 & 3.942 & 1.181 & 2.143 & 3.094 & 3.137 & 2.389 \\
\hline & 100 & 2.332 & 3.541 & 4.940 & 6.266 & 4.270 & 1.193 & 2.245 & 3.308 & 3.832 & 2.645 \\
\hline & Mean & 2.043 & 2.960 & 3.871 & 4.854 & 3.432 & 1.126 & 1.748 & 2.226 & 2.561 & 1.915 \\
\hline \multicolumn{2}{|c|}{ L.S.D. at $(0.05)$} & 0.274 & 0.643 & 1.277 & 1.643 & & 0.211 & 0.417 & 1.002 & 1.085 & \\
\hline \multirow{6}{*}{ HAP } & 0 & 1.733 & 2.386 & 2.919 & 3.565 & 2.651 & 1.039 & 1.146 & 1.286 & 1.755 & 1.307 \\
\hline & 25 & 1.935 & 2.453 & 3.022 & 3.658 & 2.767 & 1.251 & 1.620 & 1.970 & 2.402 & 1.811 \\
\hline & 50 & 2.010 & 2.718 & 3.438 & 4.472 & 3.160 & 1.512 & 2.427 & 2.760 & 2.837 & 2.384 \\
\hline & 75 & 2.290 & 2.989 & 4.776 & 5.845 & 3.975 & 1.746 & 2.543 & 3.511 & 4.550 & 3.088 \\
\hline & 100 & 2.451 & 3.469 & 5.696 & 7.093 & 4.677 & 2.749 & 2.967 & 4.737 & 5.691 & 4.036 \\
\hline & Mean & 2.084 & 2.803 & 3.970 & 4.927 & 3.446 & 1.659 & 2.141 & 2.853 & 3.447 & 2.525 \\
\hline \multicolumn{2}{|c|}{ L.S.D. at $(0.05)$} & 0.281 & 0.675 & 1.288 & 1.721 & & 0.536 & 0.518 & 1.023 & 1.283 & \\
\hline \multirow{6}{*}{ HAC } & 0 & 1.733 & 2.386 & 2.919 & 3.565 & 2.651 & 1.039 & 1.146 & 1.286 & 1.755 & 1.307 \\
\hline & 25 & 1.946 & 2.964 & 3.764 & 4.902 & 3.394 & 1.553 & 1.931 & 2.104 & 2.693 & 2.070 \\
\hline & 50 & 1.984 & 3.592 & 4.367 & 5.455 & 3.850 & 1.572 & 3.116 & 3.168 & 3.702 & 2.890 \\
\hline & 75 & 2.295 & 4.258 & 5.843 & 7.450 & 4.962 & 2.559 & 3.134 & 4.313 & 5.610 & 3.904 \\
\hline & 100 & 2.460 & 4.859 & 6.588 & 8.820 & 5.682 & 3.014 & 3.553 & 4.748 & 5.997 & 4.328 \\
\hline & Mean & 2.084 & 3.612 & 4.696 & 6.038 & 4.108 & 1.947 & 2.576 & 3.124 & 3.952 & 2.900 \\
\hline \multicolumn{2}{|c|}{ L.S.D. at (0.05) } & 0.384 & 0.747 & 1.461 & 1.984 & & 0.561 & 0.549 & 1.045 & 1.327 & \\
\hline \multirow{5}{*}{ Mean } & 0 & 1.733 & 2.386 & 2.919 & 3.565 & 2.651 & 1.039 & 1.146 & 1.286 & 1.755 & 1.307 \\
\hline & 25 & 1.937 & 2.702 & 3.340 & 4.238 & 3.054 & 1.291 & 1.670 & 1.848 & 2.356 & 1.791 \\
\hline & 50 & 2.011 & 3.070 & 3.798 & 4.860 & 3.435 & 1.411 & 2.430 & 2.633 & 2.881 & 2.339 \\
\hline & 75 & 2.256 & 3.510 & 5.096 & 6.309 & 4.293 & 1.829 & 2.607 & 3.639 & 4.431 & 3.127 \\
\hline & 100 & 2.414 & 3.956 & 5.741 & 7.393 & 4.876 & 2.319 & 2.922 & 4.264 & 5.173 & 3.670 \\
\hline \multicolumn{2}{|c|}{ General means } & 2.070 & 3.125 & 4.179 & 5.273 & 3.662 & 1.578 & 2.155 & 2.734 & 3.319 & 2.447 \\
\hline \multicolumn{2}{|c|}{ L.S.D. at $(0.05)$} & 0.301 & 0.700 & 1.375 & 1.759 & & 0.529 & 0.545 & 1.031 & 1.289 & \\
\hline
\end{tabular}


TABLE 4 Relative increase (RI,\%) of shoots and roots dry weight of sorghum as affected by different sources and rates of humic acids under four application rates of $\mathrm{Ca}$ (mean values of two seasons)

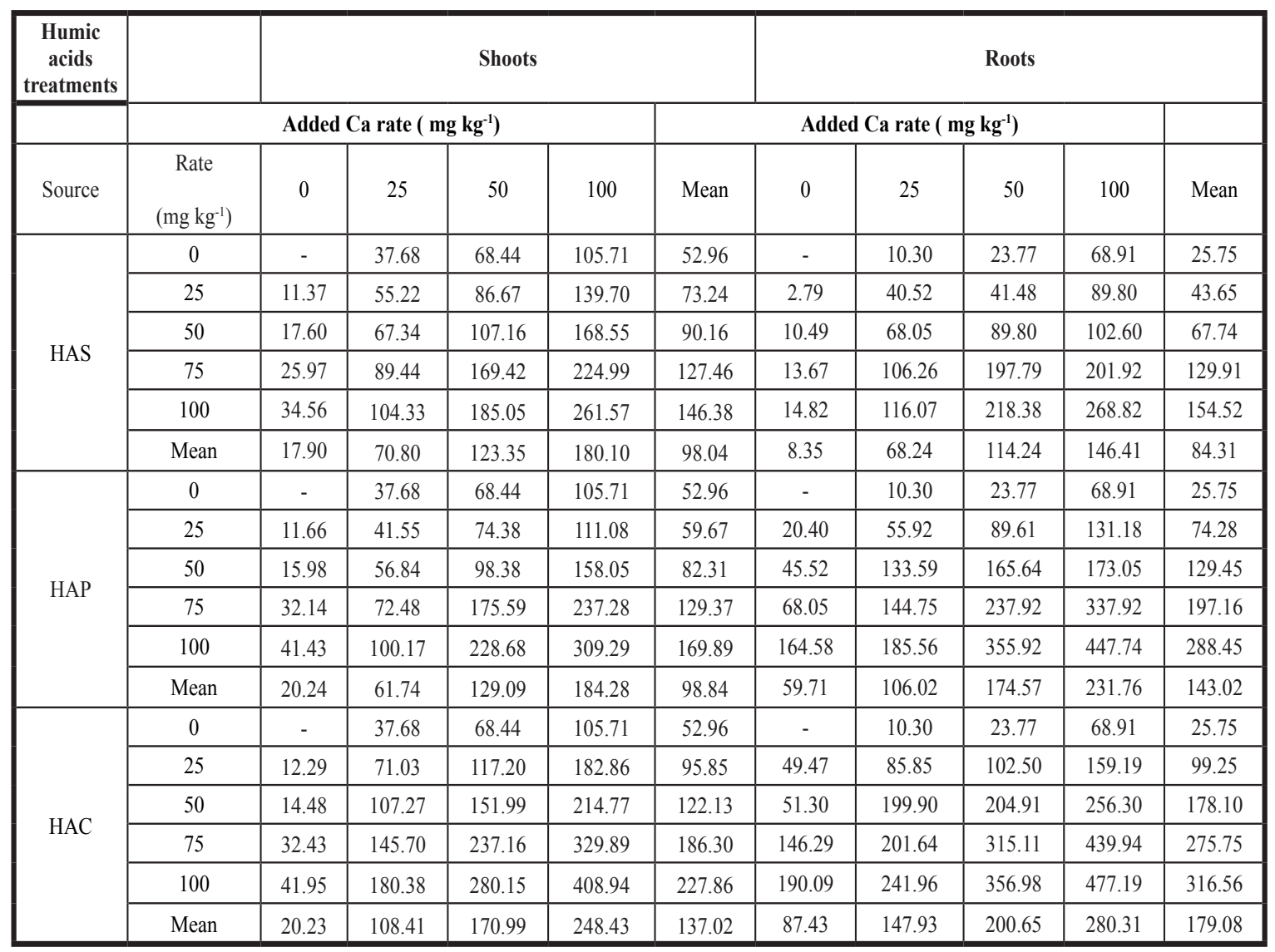

Individual applications of $\mathrm{Fe}$ effect on sorghum plants (shoots and roots) calculated as g pot1 have a significant increases as shown in Table 5 and Fig. $3 \& 4$. These increases were more clear at high rates of added $\mathrm{Fe}$ as shown from the calculated RI (\%) values for both shoots and roots (Table $6)$. At the same rate of $\mathrm{Fe}$ applications, dry matter yields of shoots and its RI were higher than those of roots. This trend means that, Fe application have a greater effect on growth compared with that observed with that of roots. The beneficial effect of $\mathrm{Fe}$ on yield may be attributed to the enhancement effect of $\mathrm{Fe}$ on respiration and photosynthesis processes and many enzymes activities like chlorophyll synthesis. These results are comparable to those reported by Mohammad et al. (2009) on wheat ; Eisa and Taha (2010) on wheat and Helmy (2015) on maize.

Regarding to the specific effect of different individual applications of both $\mathrm{Ca}$ and $\mathrm{Fe}$ on the dry matter yield (g pot-1) of sorghum plants (shoots and roots) as listed in Tables (3 and 5) may be observed that, at the same rates of $\mathrm{Ca}$ or $\mathrm{Fe}$, the found dry matter yields of both shoots and roots of sorghum plants treated by Fe were higher than those found in the plants treated by $\mathrm{Ca}$. So, RI values $(\%)$ of dry matter yields of sorghum plants treated by $\mathrm{Fe}$ were high positive compared with these calculated for sorghum plants treated by $\mathrm{Ca}$. This means that, Fe application to sorghum plants is very important to obtain on high yield of this plant. So, fertilization program of sorghum plants must be include Fe application.

Data in Tables 5 \& 6 and Fig. 3 \& 4 showed that, the combined effect of three humic acids varied in their resources and $\mathrm{Fe}$ at different application rates on both dry matter yield (g pot-1) of sorghum plants ( shoots and roots) and their relative increase (RI, \%). These data showed a significant increase of the found dry matter yield of sorghum plants and its relative increase as a result of humic acids and $\mathrm{Fe}$ application together. The high yields of dry matter of sorghum plants were found at high application rates of humic acid and $\mathrm{Fe}$, where the highest values were found in the plants treated by HAC with $\mathrm{Fe}$, but the lowest values were found in the plants treated by HAS with Fe. In this respect, Taha et al. (2006); Alhendawi et al. (2008); Eisa and Taha (2010) and Colombo et al. (2014) obtained on similar results. 
TABLE 5 . Dry matter yield of shoots and roots $\left(\mathrm{g} \mathrm{pot}^{-1}\right)$ of sorghum as affected by different sources and rates of humic acids under four application rates of $\mathrm{Fe}$ (mean values two seasons)

\begin{tabular}{|c|c|c|c|c|c|c|c|c|c|c|c|}
\hline \multirow{3}{*}{$\begin{array}{c}\begin{array}{c}\text { Humic } \\
\text { acids treat- } \\
\text { ments }\end{array} \\
\text { Source }\end{array}$} & & \multicolumn{5}{|c|}{ Shoots } & \multicolumn{5}{|c|}{ Roots } \\
\hline & \multicolumn{5}{|c|}{ Added Fe rate $\left(\mathrm{mg} \mathrm{kg}^{-1}\right)$} & \multicolumn{5}{|c|}{ Added Fe rate $\left(\mathrm{mg} \mathrm{kg}^{-1}\right)$} & \multirow[b]{2}{*}{ Mean } \\
\hline & $\begin{array}{c}\text { Rate } \\
\left(\mathrm{mg} \mathrm{kg}^{-1}\right)\end{array}$ & 0 & 25 & 50 & 100 & Mean & 0 & 25 & 50 & 100 & \\
\hline \multirow{6}{*}{ HAS } & 0 & 1.733 & 2.694 & 3.186 & 4.613 & 3.057 & 1.039 & 1.460 & 1.570 & 2.245 & 1.578 \\
\hline & 25 & 1.930 & 2.915 & 3.309 & 4.711 & 3.217 & 1.068 & 1.492 & 1.790 & 2.386 & 1.684 \\
\hline & 50 & 2.038 & 3.149 & 3.444 & 4.895 & 3.383 & 1.148 & 1.696 & 1.900 & 2.810 & 1.888 \\
\hline & 75 & 2.183 & 3.260 & 3.862 & 5.523 & 3.709 & 1.181 & 1.806 & 1.947 & 2.826 & 1.939 \\
\hline & 100 & 2.332 & 3.530 & 4.034 & 6.347 & 4.062 & 1.193 & 1.868 & 2.104 & 3.250 & 2.104 \\
\hline & Mean & 2.043 & 3.110 & 3.567 & 5.218 & 3.486 & 1.126 & 1.664 & 1.862 & 2.703 & 1.839 \\
\hline \multicolumn{2}{|c|}{ L.S.D. at $(0.05)$} & 0.274 & 0.274 & 0.699 & 1.235 & & 0.211 & 0.211 & 0.737 & 1.220 & \\
\hline \multirow{6}{*}{ HAP } & 0 & 1.733 & 2.694 & 3.186 & 4.613 & 3.057 & 1.039 & 1.460 & 1.570 & 2.245 & 1.578 \\
\hline & 25 & 1.935 & 2.817 & 3.321 & 4.748 & 3.204 & 1.251 & 1.837 & 1.994 & 2.638 & 1.931 \\
\hline & 50 & 2.010 & 2.866 & 3.592 & 4.982 & 3.361 & 1.512 & 2.104 & 2.229 & 3.140 & 2.245 \\
\hline & 75 & 2.290 & 3.198 & 4.071 & 5.929 & 3.872 & 1.746 & 2.591 & 2.857 & 4.004 & 2.799 \\
\hline & 100 & 2.451 & 3.690 & 4.797 & 7.454 & 4.597 & 2.749 & 3.988 & 4.192 & 6.437 & 4.341 \\
\hline & Mean & 2.084 & 3.053 & 3.793 & 5.545 & 3.604 & 1.659 & 2.396 & 2.568 & 3.693 & 2.579 \\
\hline \multicolumn{2}{|c|}{ L.S.D. at $(0.05)$} & 0.281 & 0.281 & 0.687 & 1.254 & & 0.536 & 0.536 & 0.764 & 1.310 & \\
\hline \multirow{6}{*}{$\mathrm{HAC}$} & 0 & 1.733 & 2.694 & 3.186 & 4.613 & 3.057 & 1.039 & 1.460 & 1.570 & 2.245 & 1.578 \\
\hline & 25 & 1.946 & 3.087 & 3.272 & 4.895 & 3.299 & 1.553 & 2.167 & 2.543 & 3.470 & 2.434 \\
\hline & 50 & 1.984 & 3.235 & 3.739 & 5.166 & 3.530 & 1.572 & 2.481 & 3.894 & 5.260 & 3.301 \\
\hline & 75 & 2.295 & 3.309 & 4.416 & 6.236 & 4.065 & 2.559 & 4.066 & 4.490 & 6.359 & 4.369 \\
\hline & 100 & 2.460 & 3.727 & 4.846 & 7.454 & 4.622 & 3.014 & 4.255 & 4.710 & 7.348 & 4.832 \\
\hline & Mean & 2.084 & 3.210 & 3.892 & 5.673 & 3.715 & 1.947 & 2.886 & 3.441 & 4.936 & 3.303 \\
\hline \multicolumn{2}{|c|}{ L.S.D. at $(0.05)$} & 0.348 & 0.384 & 0.734 & 1.307 & & 0.561 & 0.561 & 0.783 & 1.340 & \\
\hline \multirow{5}{*}{ Mean } & 0 & 1.733 & 2.694 & 3.186 & 4.613 & 3.057 & 1.039 & 1.460 & 1.570 & 2.245 & 1.578 \\
\hline & 25 & 1.937 & 2.940 & 3.301 & 4.785 & 3.240 & 1.291 & 1.832 & 2.109 & 2.831 & 2.016 \\
\hline & 50 & 2.011 & 3.083 & 3.592 & 5.014 & 3.425 & 1.411 & 2.094 & 2.674 & 3.737 & 2.478 \\
\hline & 75 & 2.256 & 3.256 & 4.116 & 5.896 & 3.882 & 1.829 & 2.821 & 3.098 & 4.396 & 3.036 \\
\hline & 100 & 2.414 & 3.649 & 4.559 & 7.085 & 4.427 & 2.319 & 3.370 & 3.669 & 5.678 & 3.759 \\
\hline \multicolumn{2}{|c|}{ General mean } & 2.070 & 3.124 & 3.751 & 5.479 & 3.606 & 1.578 & 2.315 & 2.624 & 3.777 & 2.573 \\
\hline \multicolumn{2}{|c|}{ L.S.D. at $(0.05)$} & 0.301 & 0.403 & 0.704 & 1.284 & & 0.529 & 0.809 & 0.774 & 1.332 & \\
\hline
\end{tabular}


TABLE 6 . Relative increase (RI,\%) of shoots and roots dry weight of sorghum as affected by different sources and rates of humic acids under four application rates of $\mathrm{Fe}$ (mean values of two seasons)

\begin{tabular}{|c|c|c|c|c|c|c|c|c|c|c|c|}
\hline $\begin{array}{l}\text { Humic } \\
\text { acids } \\
\text { treat- }\end{array}$ & & \multicolumn{5}{|c|}{ Shoots } & \multirow{2}{*}{\multicolumn{4}{|c|}{ Added Fe rate $\left(\mathrm{mg} \mathrm{kg}^{-1}\right)$}} & \\
\hline & \multicolumn{5}{|c|}{ Added Fe rate $\left(\mathrm{mg} \mathrm{kg}^{-1}\right)$} & Added Fe rate $\left(\mathrm{mg} \mathrm{kg}^{-1}\right)$ & & & & & \\
\hline Source & $\begin{array}{c}\text { Rate } \\
\left(\mathrm{mg} \mathrm{kg}^{-1}\right)\end{array}$ & 0 & 25 & 50 & 100 & Mean & 0 & 25 & 50 & 100 & Mean \\
\hline \multirow{6}{*}{ HAS } & 0 & - & 55.45 & 83.84 & 166.19 & 76.37 & - & 40.52 & 51.11 & 116.07 & 51.93 \\
\hline & 25 & 11.37 & 68.21 & 90.94 & 171.84 & 85.59 & 2.79 & 43.60 & 72.28 & 129.64 & 62.08 \\
\hline & 50 & 17.60 & 81.71 & 98.73 & 182.46 & 95.13 & 10.49 & 63.23 & 82.87 & 170.45 & 81.76 \\
\hline & 75 & 25.97 & 88.11 & 122.85 & 218.70 & 113.91 & 13.67 & 73.82 & 87.39 & 171.99 & 86.72 \\
\hline & 100 & 34.56 & 103.69 & 132.78 & 266.24 & 134.32 & 14.82 & 79.79 & 102.50 & 212.80 & 102.48 \\
\hline & Mean & 17.90 & 79.43 & 105.83 & 201.09 & 101.06 & 8.35 & 60.19 & 79.23 & 160.19 & 76.99 \\
\hline \multirow{6}{*}{ HAP } & 0 & - & 55.45 & 83.84 & 166.19 & 76.37 & - & 40.52 & 51.11 & 116.07 & 51.93 \\
\hline & 25 & 11.66 & 62.55 & 91.63 & 173.98 & 84.96 & 20.40 & 76.80 & 91.92 & 153.90 & 85.76 \\
\hline & 50 & 15.98 & 65.38 & 107.27 & 187.48 & 94.03 & 45.52 & 102.50 & 114.53 & 202.21 & 116.19 \\
\hline & 75 & 32.14 & 84.54 & 134.91 & 242.12 & 123.43 & 68.05 & 149.37 & 174.98 & 285.37 & 169.44 \\
\hline & 100 & 41.43 & 112.93 & 176.80 & 330.12 & 165.32 & 164.58 & 283.83 & 303.46 & 519.54 & 317.85 \\
\hline & Mean & 20.24 & 76.17 & 118.89 & 219.98 & 108.82 & 59.71 & 130.60 & 147.20 & 255.42 & 148.23 \\
\hline \multirow{6}{*}{ HAC } & 0 & - & 55.45 & 83.84 & 166.19 & 76.37 & - & 40.52 & 51.11 & 116.07 & 51.93 \\
\hline & 25 & 12.29 & 78.13 & 88.81 & 182.46 & 90.42 & 49.47 & 108.57 & 144.75 & 233.97 & 134.19 \\
\hline & 50 & 14.48 & 86.67 & 115.75 & 198.10 & 103.75 & 51.30 & 138.79 & 274.78 & 406.26 & 217.78 \\
\hline & 75 & 32.43 & 90.94 & 154.82 & 259.84 & 134.51 & 146.29 & 291.34 & 332.15 & 512.03 & 320.45 \\
\hline & 100 & 41.95 & 115.06 & 179.63 & 330.12 & 166.69 & 190.09 & 309.53 & 353.32 & 607.22 & 365.04 \\
\hline & Mean & 20.23 & 85.25 & 124.57 & 227.34 & 114.35 & 87.43 & 177.75 & 231.22 & 375.11 & 217.88 \\
\hline
\end{tabular}

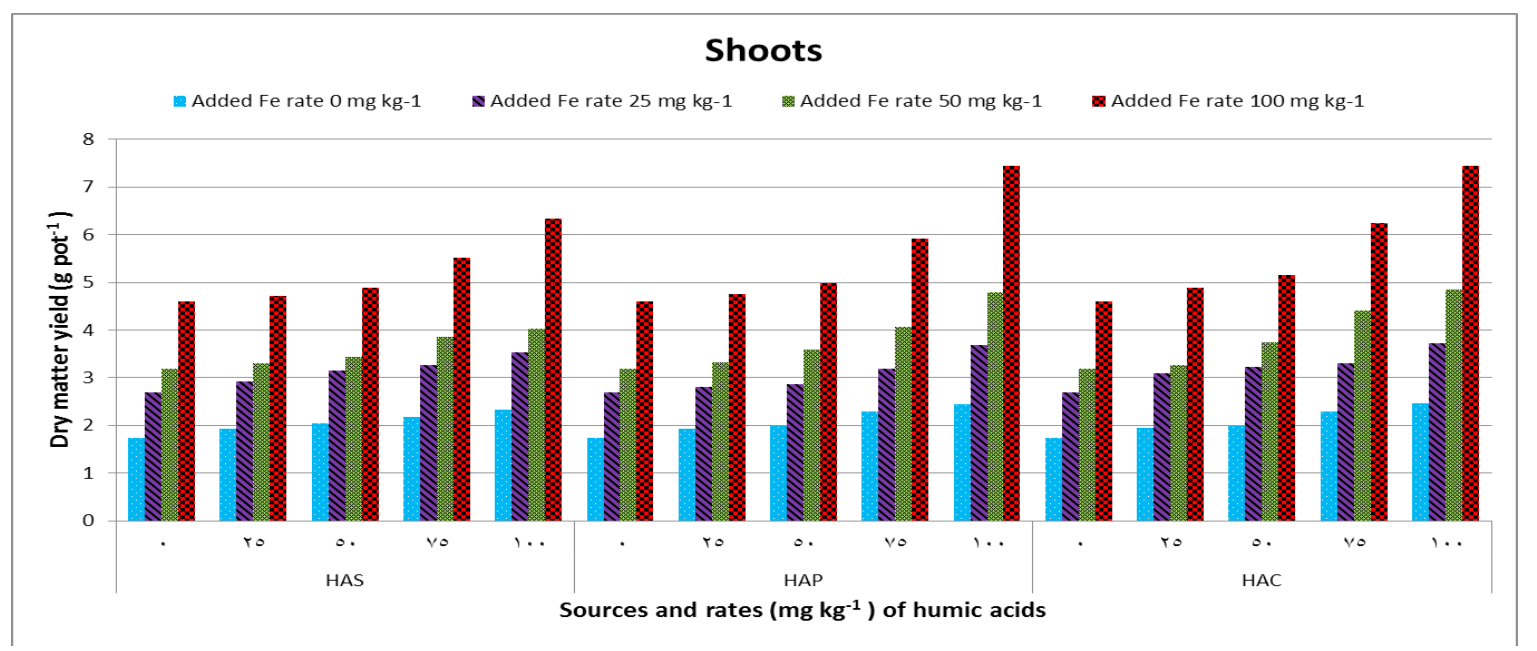

Fig. 1. Effect of different sources and rates of humic acids on shoots dry matter yield of sorghum plants under different application rates of $\mathrm{Ca}$ 


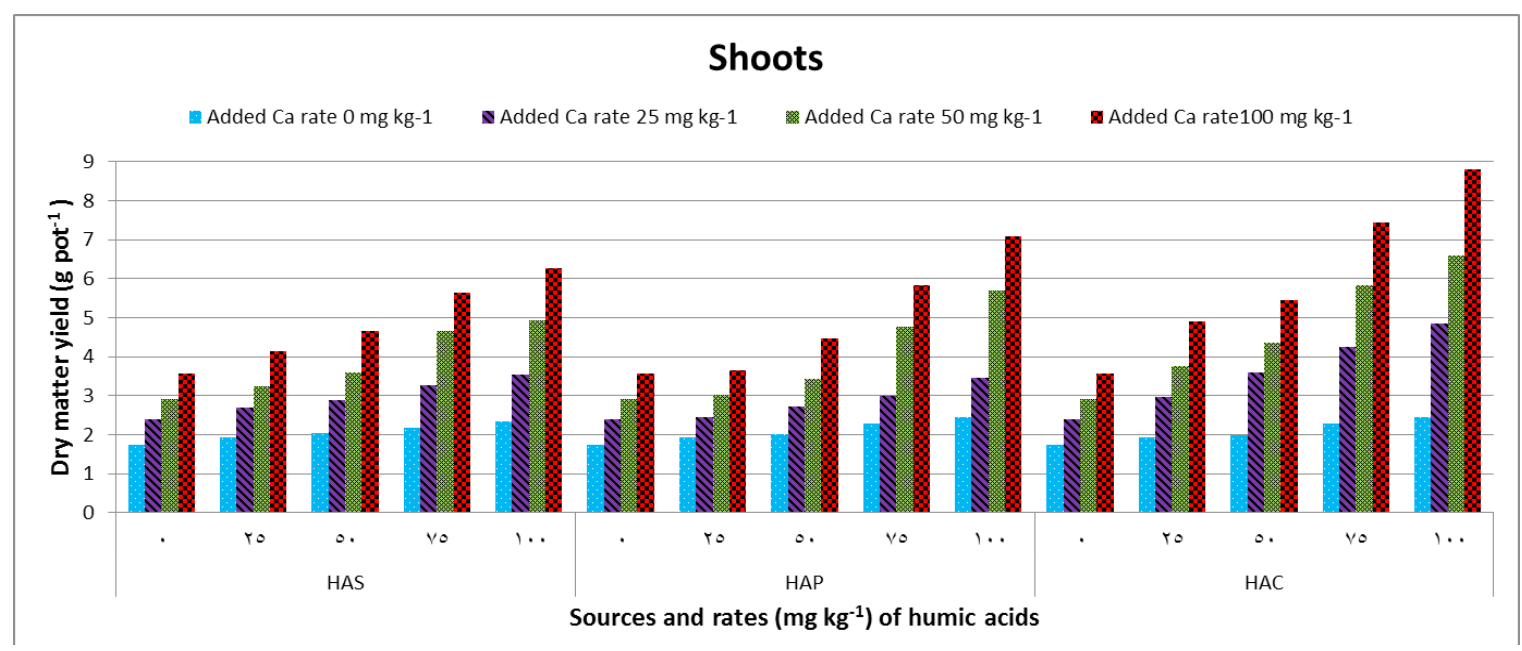

Fig. 2. Effect of different sources and rates of humic acids on roots dry matter yield of sorghum plants under different application rates of $\mathrm{Ca}$

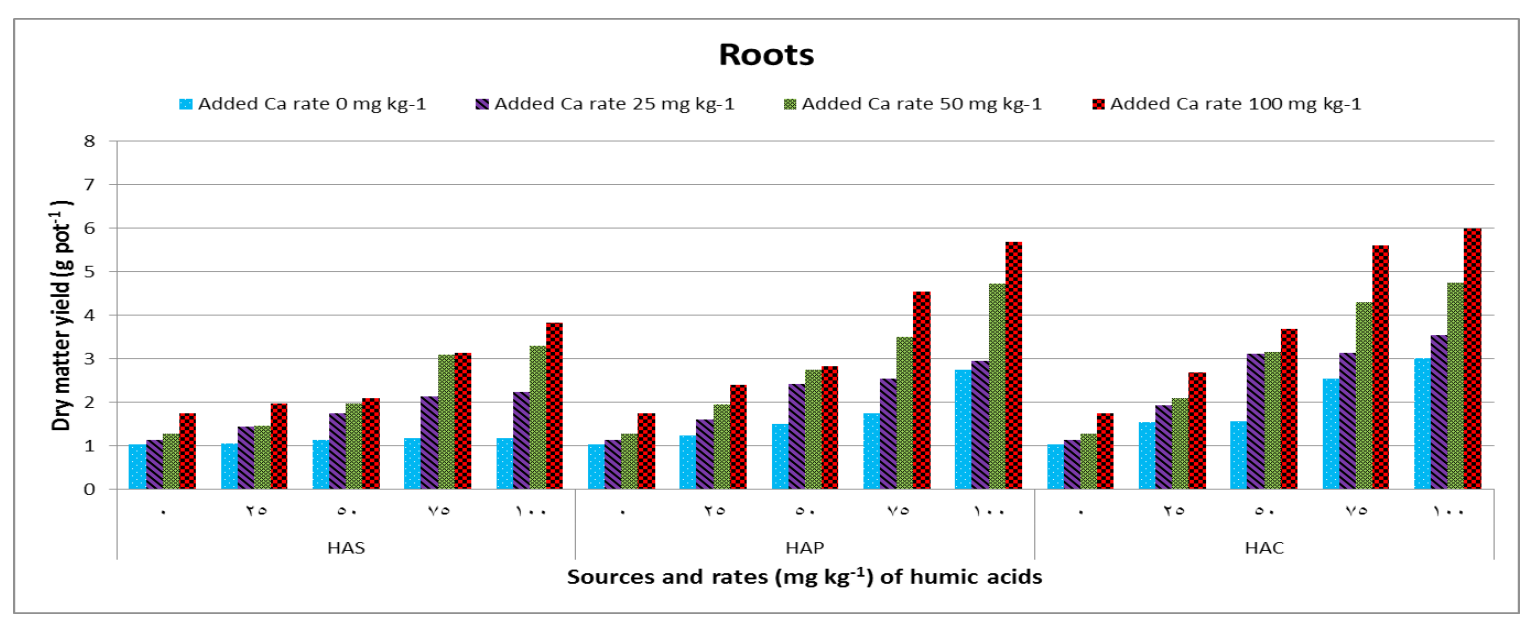

Fig. 3. Effect of different sources and rates of humic acids on shoots dry matter yield of sorghum plants under different application rates of $\mathrm{Fe}$

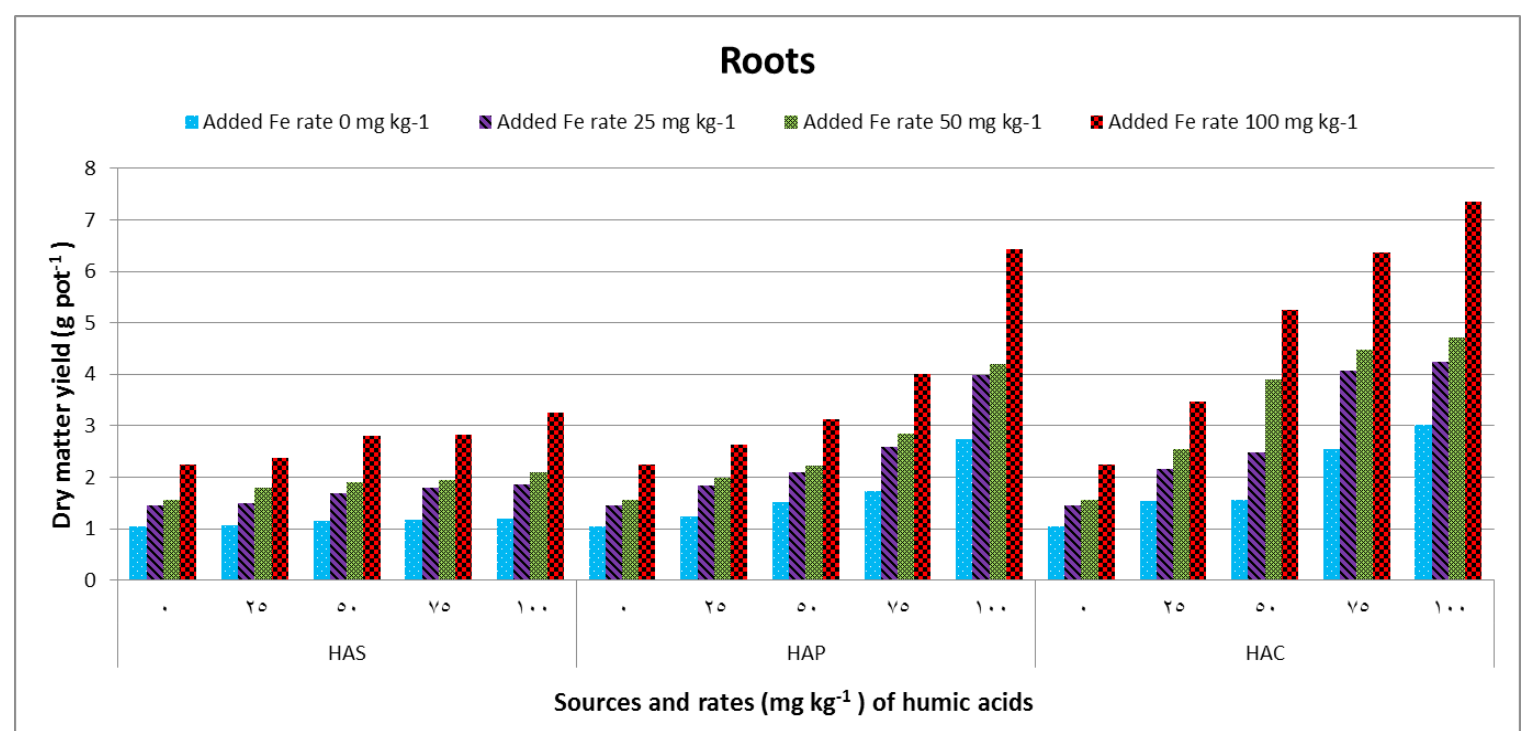

Fig. 4. Effect of different sources and rates of humic acids on roots dry matter yield of sorghum plants under different application rates of $\mathbf{F e}$

Egypt. J. Soil. Sci. 58, No. 3 (2018) 


\section{Calcium uptake}

Data in Table 7 showed that, Ca uptake (mg pot1) affected by individual and combined applications of the used three humic acids and $\mathrm{Ca}$. These data showed, individual applications of humic acids resulted in a slight increase of Ca uptake by both shoots and roots. On the other hand, significant increase of $\mathrm{Ca}$ uptake was resulted from the individual $\mathrm{Ca}$ applications. More increases of $\mathrm{Ca}$ uptake by shoots and roots of sorghum plants were found in the plants treated by the combined applications of humic acids and $\mathrm{Ca}$. These increase are in harmony with the effect of the studied treatments (humic acids and $\mathrm{Ca}$ ) on the dry matter yield of sorghum plants either shoots and roots. At the same application rate of humic acid and $\mathrm{Ca}$ in combined applications, the highest $\mathrm{Ca}$ uptake by shoots and roots was found in the plants treated by HAC followed by that found with HAP application. This order is harmony with the chemical composition of the used humic acids and their content of $\mathrm{Ca}$ (Tables, 1 and 2). This finding in the current study is supported by Asik et al. (2009); Katkat et al. (2009); Hussein and Hassan (2011) and Mohamed (2012).

\section{Iron uptake}

Iron uptake (mg pot-1) by sorghum plants (shoots and roots) affected by individual and combined applications of the used three humic acids and $\mathrm{Fe}$ was studied and the obtained data recorded in Table (8). These data showed that, a slight increase of Fe uptake by both shoots and roots as a result of individual applications of humic acids, where the added three humic acids may be arranged according to their effect on Fe uptake by sorghum plants in the following order: HAC $>$ HAP $>$ HAS. This order are in harmony with both the chemical composition of the used humic acids especially their content of Fe (Tables, 1 and 2) and their effect on the dry matter yields of sorghum plants (Table, 5). Individual applications of Fe resulted in a significant increase of Fe uptake (mg/ pot) by shoots and roots of sorghum plants. These results attributed to high content of soluble Fe in the growth media and its effect on the increase of sorghum dry matter yield. Before that, Lemanceau et al. (2009); Mohammad et al. (2009); Eisa and Taha (2010) and Colombo et al. (2014) obtained on similar results. More increases of $\mathrm{Fe}$ uptake by shoots and roots of sorghum plants were observed in the plants treated by humic acids and Fe together. These results are in agreement with those obtained by Mackowiak et al. (2001); Salib (2002); Sanchez et al. (2006); Alhendawi et al. (2008) and Morard et al. (2011).

\section{Calcium and iron utilization}

The presented data in Tables 9 and 10 showed that, the $\mathrm{Ca}$ and $\mathrm{Fe}$ utilization by shoots and roots of sorghum plants treated by three humic acids at different application rate when its added as alone or in combination with $\mathrm{Ca} \mathrm{OAC}$ or $\mathrm{Fe} \mathrm{OAC}$. Increasing rate of added humic acids resulted in an increases of both $\mathrm{Ca}$ and $\mathrm{Fe}$ utilization by both shoots and roots of sorghum plants. Such increases attributed to enhanced effect of added humic acids on plant growth and the yields of dry matter yield as mentioned before that by Morard et al. (2011); Mohamed (2012) ; Nada and Tantawy (2012) and Abd El-Kader (2016).

At the same application rate of the used three humic acids, the obtained data pointed the following points: 1) Utilization rates of $\mathrm{Ca}$ and $\mathrm{Fe}$ with shoots were higher than those found for roots which are in harmony with the found dry matter yields for both shoots and roots, 2) With both shoots and roots, utilization rates of $\mathrm{Ca}$ were higher than those obtained for Fe, which may be attributed to the high dry matter yields of sorghum plants (shoots and roots) resulted from $\mathrm{Ca}$ applications compared with those resulted from $\mathrm{Fe}$ application and 3) According to the found utilization rate of $\mathrm{Ca}$ and $\mathrm{Fe}$ by both shoots and roots, the used three humic acids takes the order: HAC > HAP $>$ HAS, where this order attributed two main resource's. The first is the chemical composition of these acids and their content of both functional groups and essential plant nutrients (Tables, 1 and 2), and the second is the effect of the added humic acids on the obtained dry matter yields of sorghum plants. In addition, the obtained data also showed that, utilization rates (\%) of both $\mathrm{Ca}$ and Fe clearly decreased with the increase rate of added $\mathrm{Ca}$ and $\mathrm{Fe}$. This trend was found with both shoots and roots at all application rates of the tested three humic acids. These findings means that, low application rates of $\mathrm{Ca}$ and $\mathrm{Fe}$ have a high efficiency on their uptake compared with those resulted from the high application rates. Such increments were obtained by Hepler (2005); Taha et al. (2006); Katkat et al. (2009) and Eisa and Taha (2010).

\section{Conclusion}

This study emphasized the great importance of the appropriate role of humic acids especially HAC in enhancing growth yield and promotes the uptake of $\mathrm{Ca}$ and $\mathrm{Fe}$ nutrients by sorghum plant under the grown on sandy culture. The interaction effect between humic acids and either of $\mathrm{Ca}$ or Fe application increased both sorghum yield quantity and quality. The best treatment is applying HAC at rate $100 \mathrm{mg}$ $\mathrm{kg}-1+\mathrm{Ca}$ rate $100 \mathrm{mg} \mathrm{kg}-1$ followed by HAC at rate $100 \mathrm{mg} \mathrm{kg-1}+$ Fe rate $100 \mathrm{mg} \mathrm{kg}-1$. 
TABLE 7. Calcium uptake $\left(\mathrm{mg} \mathrm{pot}^{-1}\right)$ in shoots and roots of sorghum as affected by different sources and rates of humic acids under four application rates of $\mathrm{Ca}$ (mean values of two seasons)

\begin{tabular}{|c|c|c|c|c|c|c|c|c|c|c|c|}
\hline \multicolumn{2}{|c|}{$\begin{array}{l}\text { Humic acids treat- } \\
\text { ments }\end{array}$} & \multicolumn{5}{|c|}{ Added Ca rate $\left(\mathrm{mg} \mathrm{kg}^{-1}\right)$} & \multicolumn{5}{|c|}{$\begin{array}{c}\text { Roots } \\
\text { Added Ca rate }\left(\mathrm{mg} \mathrm{kg}^{-1}\right)\end{array}$} \\
\hline Source & $\begin{array}{c}\text { Rate } \\
\left(\mathrm{mg} \mathrm{kg}^{-1}\right)\end{array}$ & 0 & 25 & 50 & 100 & Mean & 0 & 25 & 50 & 100 & Mean \\
\hline \multirow{5}{*}{ HAS } & 0 & 0.734 & 14.711 & 22.002 & 29.247 & 16.674 & 0.275 & 4.861 & 6.815 & 9.608 & 5.390 \\
\hline & 25 & 0.787 & 14.945 & 22.962 & 33.542 & 18.059 & 0.344 & 5.212 & 6.892 & 9.930 & 5.595 \\
\hline & 75 & 1.134 & 16.642 & 28.654 & 37.992 & 21.106 & 0.377 & 6.613 & 9.478 & 11.375 & 6.961 \\
\hline & 100 & 1.391 & 21.611 & 31.884 & 42.553 & 24.360 & 0.446 & 6.674 & 10.894 & 11.383 & 7.349 \\
\hline & Mean & 0.974 & 16.571 & 26.703 & 35.831 & 20.020 & 0.358 & 5.859 & 8.472 & 10.495 & 6.296 \\
\hline \multirow{4}{*}{ HAP } & 0 & 0.734 & 14.711 & 22.002 & 29.247 & 16.674 & 0.275 & 4.861 & 6.815 & 9.608 & 5.390 \\
\hline & 25 & 0.801 & 22.976 & 30.717 & 41.535 & 24.007 & 0.446 & 6.570 & 7.715 & 10.527 & 6.315 \\
\hline & 100 & 1.481 & 24.206 & 37.353 & 47.800 & 27.710 & 0.458 & 8.572 & 14.232 & 17.245 & 10.127 \\
\hline & Mean & 0.977 & 21.768 & 31.388 & 41.486 & 23.905 & 0.416 & 7.206 & 10.396 & 12.735 & 7.688 \\
\hline \multirow{6}{*}{$\mathrm{HAC}$} & 0 & 0.734 & 14.711 & 22.002 & 29.247 & 16.674 & 0.275 & 4.861 & 6.815 & 9.608 & 5.390 \\
\hline & 25 & 1.166 & 25.190 & 33.867 & 46.560 & 26.696 & 0.611 & 8.690 & 11.572 & 16.158 & 9.258 \\
\hline & 50 & 1.310 & 26.113 & 37.656 & 48.531 & 28.403 & 0.612 & 10.302 & 17.082 & 20.732 & 12.182 \\
\hline & 75 & 1.426 & 26.605 & 40.886 & 55.859 & 31.194 & 0.636 & 11.907 & 17.565 & 26.985 & 14.273 \\
\hline & 100 & 1.640 & 26.937 & 42.821 & 63.940 & 33.835 & 0.754 & 13.089 & 19.837 & 28.048 & 15.432 \\
\hline & Mean & 1.255 & 23.911 & 35.446 & 48.827 & 27.360 & 0.578 & 9.770 & 14.574 & 20.306 & 11.307 \\
\hline
\end{tabular}

TABLE 8. Iron uptake (mg pot-1) in shoots and roots of sorghum as affected by different sources and rates of humic acids under four application rates of $\mathrm{Fe}$ (mean values of two seasons)

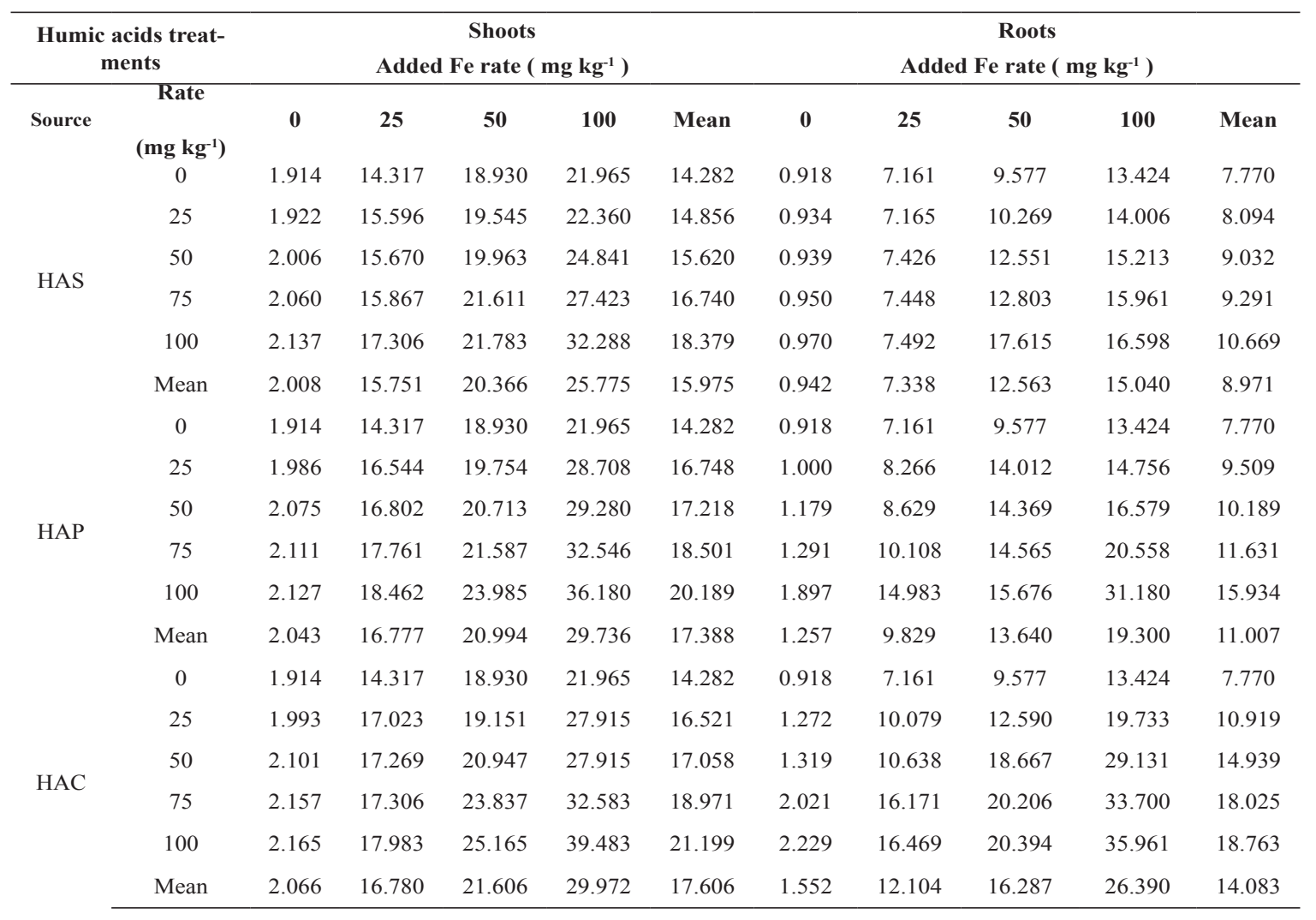

Egypt. J. Soil. Sci. 58, No. 3 (2018) 
TABLE 9. Calcium utilization (\%) by shoots and roots of sorghum as affected by different sources and rates of humic acids at four application rates of $\mathrm{Ca}$ (mean values of two seasons)

\begin{tabular}{|c|c|c|c|c|c|c|c|c|c|}
\hline \multicolumn{2}{|c|}{$\begin{array}{l}\text { Humic acids treat- } \\
\text { ments }\end{array}$} & \multicolumn{4}{|c|}{ Shoots } & \multicolumn{4}{|c|}{ Roots } \\
\hline \multirow{2}{*}{ Source } & \multirow{2}{*}{$\begin{array}{c}\text { Rate } \\
\left(\mathrm{mg} \mathrm{kg}^{-1}\right)\end{array}$} & \multicolumn{4}{|c|}{ Added Ca rate ( $\left.\mathrm{mg} \mathrm{kg}^{-1}\right)$} & \multicolumn{4}{|c|}{ Added Ca rate $\left(\mathrm{mg} \mathrm{kg}^{-1}\right)$} \\
\hline & & 25 & 50 & 100 & Mean & 25 & 50 & 100 & Mean \\
\hline \multirow{6}{*}{ HAS } & trol & 55.91 & 42.54 & 28.51 & 42.32 & 18.34 & 13.08 & 9.33 & 13.58 \\
\hline & 25 & 56.63 & 44.35 & 32.76 & 44.58 & 19.47 & 13.10 & 9.59 & 14.05 \\
\hline & 50 & 56.49 & 54.38 & 35.00 & 48.62 & 22.34 & 15.86 & 9.83 & 16.01 \\
\hline & 75 & 62.03 & 55.04 & 36.86 & 51.31 & 24.91 & 18.20 & 11.00 & 18.04 \\
\hline & 100 & 80.88 & 60.99 & 41.16 & 61.01 & 24.94 & 20.90 & 10.94 & 18.93 \\
\hline & Mean & 64.01 & 53.69 & 36.45 & 51.38 & 22.92 & 17.02 & 10.34 & 16.76 \\
\hline \multirow{5}{*}{ HAP } & 25 & 88.70 & 59.83 & 40.73 & 63.09 & 24.50 & 14.54 & 10.08 & 16.37 \\
\hline & 50 & 88.44 & 62.79 & 40.96 & 64.06 & 29.09 & 18.41 & 10.79 & 19.43 \\
\hline & 75 & 91.86 & 67.21 & 46.01 & 68.36 & 31.40 & 26.22 & 14.60 & 24.07 \\
\hline & 100 & 90.90 & 71.74 & 46.32 & 69.65 & 32.46 & 27.55 & 16.79 & 25.60 \\
\hline & Mean & 89.98 & 65.39 & 43.51 & 66.29 & 29.36 & 21.68 & 13.07 & 21.37 \\
\hline \multirow{5}{*}{ HAC } & 25 & 96.10 & 65.40 & 45.39 & 68.96 & 32.32 & 21.92 & 15.55 & 23.26 \\
\hline & 50 & 99.21 & 72.69 & 47.23 & 73.04 & 38.76 & 32.94 & 20.12 & 30.61 \\
\hline & 75 & 100.72 & 78.92 & 54.43 & 78.02 & 45.08 & 33.86 & 26.35 & 35.10 \\
\hline & 100 & 101.19 & 82.36 & 62.30 & 81.95 & 49.34 & 38.17 & 27.29 & 38.27 \\
\hline & Mean & 99.13 & 74.84 & 52.34 & 75.49 & 41.38 & 31.72 & 22.33 & 31.81 \\
\hline
\end{tabular}

TABLE 10. Iron utilization (\%) by shoots and roots of sorghum as affected by different sources and rates of humic acids at four application rates of $\mathrm{Fe}$ (mean values of two seasons)

\begin{tabular}{|c|c|c|c|c|c|c|c|c|c|}
\hline \multirow{2}{*}{ Source } & \multirow{2}{*}{$\begin{array}{c}\text { Rate } \\
\left(\mathrm{mg} \mathrm{kg}^{-1}\right)\end{array}$} & \multicolumn{4}{|c|}{ Added $\mathrm{Fe}$ rate $\left(\mathrm{mg} \mathrm{kg}^{-1}\right)$} & \multicolumn{4}{|c|}{ Added $\mathrm{Fe}$ rate $\left(\mathrm{mg} \mathrm{kg}^{-1}\right)$} \\
\hline & & 25 & 50 & 100 & Mean & 25 & 50 & 100 & Mean \\
\hline \multirow{7}{*}{ HAS } & Control & 49.61 & 34.03 & 20.05 & 28.56 & 24.97 & 17.32 & 12.51 & 18.27 \\
\hline & 25 & 54.70 & 35.25 & 20.44 & 36.80 & 24.92 & 18.67 & 13.07 & 18.89 \\
\hline & 50 & 54.66 & 35.91 & 22.84 & 37.80 & 25.95 & 23.22 & 14.27 & 21.15 \\
\hline & 75 & 55.23 & 39.10 & 25.36 & 39.90 & 25.99 & 23.71 & 15.01 & 21.57 \\
\hline & 100 & 60.68 & 39.29 & 30.15 & 43.37 & 26.09 & 33.29 & 15.63 & 25.00 \\
\hline & Mean & 56.32 & 37.39 & 24.70 & 39.47 & 25.74 & 24.72 & 14.50 & 21.65 \\
\hline & 25 & 58.23 & 35.54 & 26.72 & 40.16 & 29.06 & 26.02 & 13.76 & 22.95 \\
\hline \multirow{3}{*}{ HAP } & 50 & 58.91 & 37.28 & 27.21 & 41.13 & 29.80 & 26.38 & 15.40 & 23.86 \\
\hline & 75 & 62.80 & 38.95 & 30.44 & 44.06 & 35.27 & 26.55 & 19.27 & 27.03 \\
\hline & 100 & 65.34 & 43.72 & 34.05 & 47.70 & 52.34 & 27.56 & 29.28 & 36.39 \\
\hline \multirow{6}{*}{ HAC } & Mean & 61.32 & 38.87 & 29.61 & 43.26 & 36.62 & 26.63 & 19.43 & 27.56 \\
\hline & 25 & 60.12 & 34.32 & 25.92 & 40.12 & 35.23 & 22.64 & 18.46 & 25.44 \\
\hline & 50 & 60.67 & 37.69 & 25.81 & 41.39 & 37.28 & 34.70 & 27.81 & 33.26 \\
\hline & 75 & 60.60 & 43.36 & 30.43 & 44.80 & 56.60 & 36.37 & 31.68 & 41.55 \\
\hline & 100 & 63.27 & 46.00 & 37.32 & 48.86 & 56.96 & 36.33 & 33.73 & 42.34 \\
\hline & Mean & 61.17 & 40.34 & 29.87 & 43.79 & 46.52 & 32.51 & 27.92 & 35.65 \\
\hline
\end{tabular}




\section{References}

Abd El-Kader, N. (2016) The combined effect of urea and organic acid on some soil properties, yield and nutrient uptake by wheat crop. Egypt. J. Soil Sci., 56 (2), 281-294.

Agarwala, S. C. and Chatterjee, C. (1996) Techniques in Micronutrient Research. In: Hemantrainjan, A. (Eds.) Advancements in Micronutrient Research. Scientific Publishers, Jodhpur, India, pp. 401-453.

Alhendawi, R. A., Kirkby, E. A., Pilbeen, D. J. and Ramheld, V. (2008) Effect of iron seed dressing and form of nitrogen-supply on growth and micronutrients concentrations in shoot of sorghum grown in calcareous sand culture. J. Plant Nutr., 31 (10), 1855-1865.

Asik, B. B., Turan, M. A., Celik, H. and Katkat, A. V. (2009) Effect of humic substances on plant growth and mineral nutrients uptake of wheat (Triticum durum Cv. Salihi) under of salinity. Asian J. Crop Sci., (1), 87-95.

Awad, F., Römheld, V. and Marschner, H. (1988) Mobilization of ferric iron from a calcareous soil by phytosiderophores. J. Plant Nutrition, 11, 701.

Awad, F., Römhled, V. and Marschner, H. (1994) Effect of root exudates on mobilization in the rhizosphere and uptake of iron by wheat plants. Plant and Soil, 165, 213.

Bremmes, J.M. and Mulvaney, C.S. (1982) "Nitrogen- Total”. Pages 595- 624 in A.L. Page; R. M. Miller and D.R. Keeney (Eds.) "Methods of Soil Analysis". Part II (2nd Ed. ) : Chemical and Microbiological Properties. ASA, Inc., SSSA, Inc. Publishes, Madison, Wisconsin, USA.

Brooks, J. D. ; Durieand, R. A. and Sternhell, S. (1958). Chemistry of brown cool: 3- pyrolytic reaction. Aust. J. Appl. Sci., 9, 303- 320.

Brunetti, G., Plaza, C. and Seneri, N. (2005) Oliva pomace amendment in mediterranean conditions. Effect on soil and humic acid properties and (wheat Triticum astivum L ) yield. J. Agric. Food Chem., 53 (17), 6730-6737.

Chapman, H. D. and Pratt, P. F. (1961) "Methods of Analysis for Soils, Plants and Water". Univ. of CaliforEgypt. J. Soil. Sci. 58, No. 3 (2018) nia Agric. Sci. Preiced Publication. 4034, p 50.

Chen, Y., Senesi, N. and Schnitzer, M. (1978) Chemical and physical characteristics of humic acids extracted from soils of Mediterranean region. Geoderma, 20, 87- 104 .

Colombo, C., Palumbo, G., He, J. Z., Pinton, R. and Cesco, S. (2014) Review on iron availability in soil : interaction of Fe minerals, plants and microbes. J. Soils and Sediments, 14 (3), 538-548.

Cottenie, A., Verloo, M., Kikens, L., Velghe, G. and Camerlynek, R. (1982) "Analytics Problems and Methods in Chemical Plant and Soil Analysis". Handbook, Ed.: A. Cottenie. Ghent. Belgium.

Delserone, L. M. ( 2008) Sorghum. J. of Agric. \& Food Information, 8, 9-14.

Dragunova, A. E. (1958) “A Rapid Method for Determining Functional Groups in Humic Acids". Nauch. Trydy. Mosk. In. Zh-a Konon. Inst. Ser. Khi. Droizvod. C. F. Kononova (1966) pp. 410.

Eisa, Salaw A. and Taha, M. B. (2010) Improving soil productivity for wheat plants by adding humic acid and iron - chelates. Egypt. J. Soil Sci. 50 (1), 15-26.

FAO, Food and Agriculture Organization (2012) Sorghum bicolor (L.) Moench. In: Grassland Species Profiles Database [online.www.fao.org/ag/agp/ agpc/doc/gbase/data/pf000319.htm]. (accessed 17 July 2012).

Fouda, S., Sabine, V. T., Fabbian, L. and Urs, S. (2013) Availability of various biogas residues applied to ryegrass. J. of Plant Nutri. and Soil Sci. 176 (40), 572-584.

Gomez, K. A. and Gomez, A. A. (1984) "Statistical Procedures for Agricultural Research”. 2nd ed., Wiley, New York.

Helmy, A. M. (2015) Mutual effect among some organic substances and micronutrients on maize ( $\mathrm{Zea}$ mays L.) grown on sandy soil. Egypt. J. Soil Sci., 55 ( 3), 303-317.

Hepler, P. K. (2005) Calcium: A central regulator of plant growth and development. J. of American Society of Plant Biologists, 17 (8), 2142-2155. 
Holder, M. P. and Griffith, S. M. (1983) Some characterization of humic materials in Caribbean vertisals. Can. J. Soil Sci. 63, 151- 159.

Hussein, K. H. and Hassan, A. F. (2011) Effect of different humic acids on the nutrient content, plant growth and soil properties under conditions of salinity. Soil and Water Res., 6 (1), 21-29.

Kappler, A., Benz, M., Brun, A. and Schink, B. (2004) Electron shuttling via humic acids in microbial iron (III) reduction in a fresh water sediment. FEMS Microbiol. Ecol., 47, 85-92.

Katkat, A.V., Celik, H.,Turan, M. A. and Asik, B. B. (2009) Effect of soil and foliar applications of humic substances on dry weight and mineral nutrients uptake of wheat plant under calcareous soil conditions. Austr. J. of Basic and Appl. Sci., 3(2), 1266-1273.

Kononova, M.M. (1966) “Soil Organic Matter Pergamon", Oxford, pp. 190-199.

Kukhareko, T.A. (1937) "Reactions of Humic Acids With Neutral Salts". Part 1. Khin. Tverd. Tool. 8 (9) \& part.1 hid.8 (12) (C.F. Kononova 1966, pp. 411- 412 ).

Lemanceau, P., Expert, D., Gaymard, F., Bakker, P. A. and Briat, J. F. (2009) Role of iron in plantmicrobe interactions. Plant Innate Immune, 51, 491-549

Mackowiak, C. L., Grossl, P. R. and Bugbee, B. G. (2001) Beneficial effects of humic acid on micronutrient availability to wheat. Soil Sci. Soc. Am. J. 65, 1744- 1750 .

Mann, F. G. and Sounders, B. C. (1966) "Practical Organic Matter". 4th ed. Western Printing Services, L.T.D. Bristol.

Marschner, H. (2012) "Mineral Nutrition of Higher Plants". 3rd ed. Edited by Petra Marschner.

Mohammad, R., Pahlavan-Rad, R. and Pessarakli, M. (2009) Response of wheat plants to zinc, iron and manganese application on uptake and concentrations of zinc, iron and manganese in wheat grains. Commu. Soil Sci. Plant Anal. 40 (7 and 8 ), 1322 -1332 .
Mohamed, W. H. (2012) Effect of humic acid and calcium forms on dry weight and nutrient uptake of maize plant under saline condition. Austr. J. Basic and Appl. Sci., 6 (8): 597 - 604.

Montaser, F. A., Mamdoh, E. I. and Kadry, M. M. (2011) Induction of systemic resistance of benzothiadiazole and humic acid in soya bean plants against fusarium wilt disease. J. Mycobiology, 39 (4), $290-298$.

Morard, P., Eyheraguibel, B., Morard, M. and Silvestre, J. (2011) Direct effect of humic acid-like substance on growth, water and mineral nutrition of various species. J. Plant Nutr., 34 (1), 46-59.

Nada, W. M. and Tantawy, Manal F. (2012) Effect of humic acid applications on soil properties and plant tolerance for high salinity levels of irrigation water. Egypt. J. Soil Sci., 52 (4), 507-525.

Nardi, S., Pizzeghello, D., Muscolo, A. and Vianello, A. (2002) Physiological effects of humic substances on higher plants. Soil Biol. Biochem. 34, 1527-1536.

Olsen, S. R. and Sommers, L. E. (1982) "Phosphorus". Pages 403-430. In A.L. Page, R. M. Miller and D.R. Keency (Ed.) "Methods of Soil Analysis". Part (2nd ed. ): "Chemical and Microbiological Properties". ASA, Inc., SSSA, Inc. Publishes, Madison, Wisconsin, USA.

Posner, A. M. (1966) The humic acid extracted by various reagents from a soil. Part 1. Yield in organic components and titration curves. J. Soil Sci., 17, 65-78.

Salib, M. M. (2002) The integrated effect of humic acid and micronutrients in combination with effective micro-organisms on wheat and peanut grown on sandy soils. Zagazig J. Agric. Res., 29 (6), 2033-2050.

Sanchez, A., Andreu, J. S., Tuarez, M., Jarda, L. and Bermudez, D. (2006) Improvement of iron uptake in table grape by addition of humic substances. $J$. Plant Nutr., 29 (2): 259-272.

Schnitzer, M. and Khan, S. U. (1978) "Soil Organic Matter". El-Sevier Scientific Publishing Company Amsterdam, Oxford, New York. 
Taha, A. A., Modaish, S. A. and Mahgoub, M. O. (2006) Effect of some humic acids on wheat plant grown in different soils. J. Agric. Sci. Mansoura Univ., 31 (6), 4031 - 4039.

Tuna, A. L., Kaya, C., Ashraf, M., Altunlu, H.,Yokas, I. and Yagmur, A. (2007) The effects of calcium sulphate on growth, membrane stability and nutrient uptake of tomato plants grown under salt stress. Environmental and Experimental Botany, 59, 173-178.

Turan, M. A., Asik, B. B., Katkat, A.V. and Celik, H. (2011) The effects of soil applied humic substances to the dry weight and mineral nutrient uptake of maize plants under soil salinity conditions. Not. Bot. Hort. Agrobot. Cluj., 39 (1), 171-177.

(Received: 16/4/2018;

accepted:24/7/2018 ) 


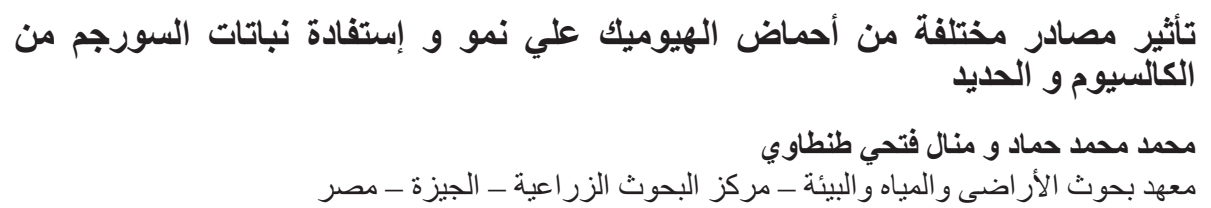

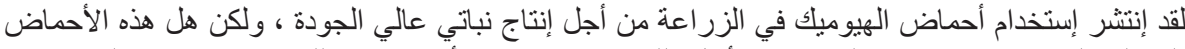

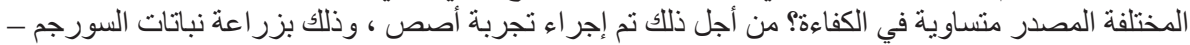

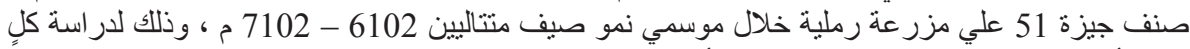

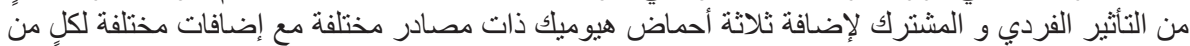

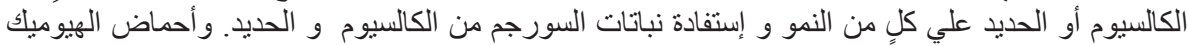

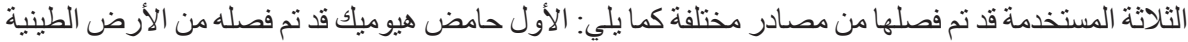

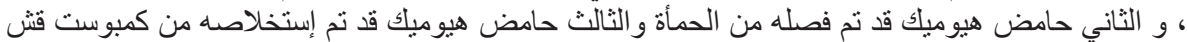

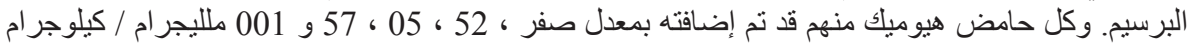

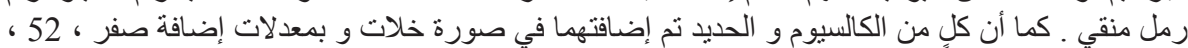

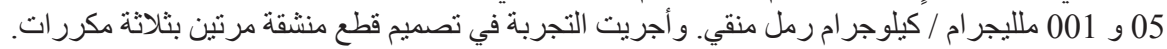

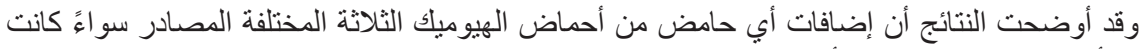

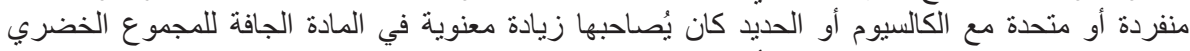

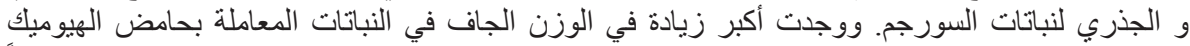

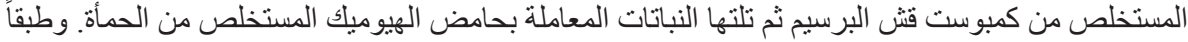

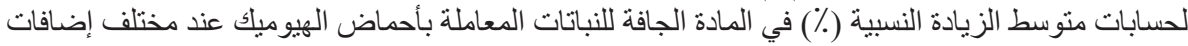

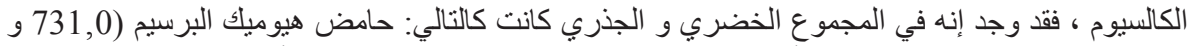

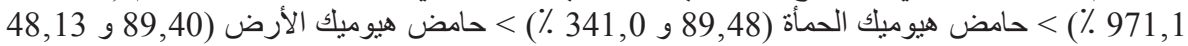

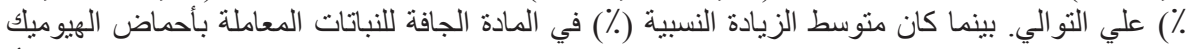

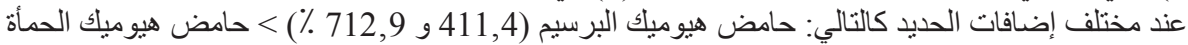

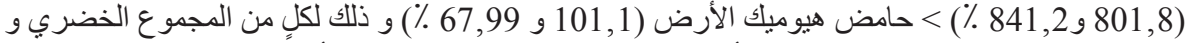

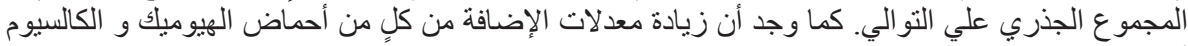

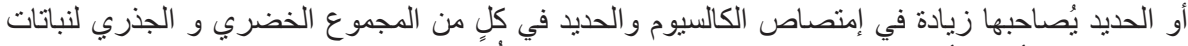

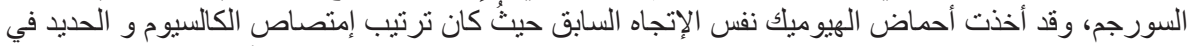

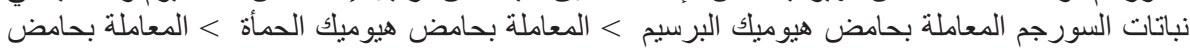

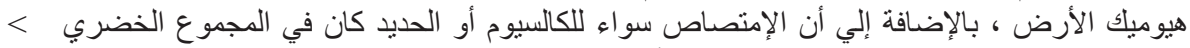

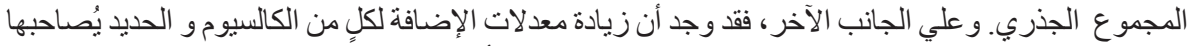

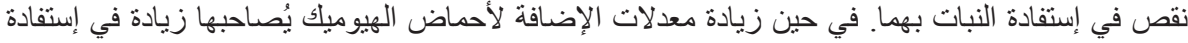
النبات للكالسيو و والحديد.

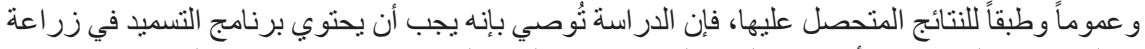

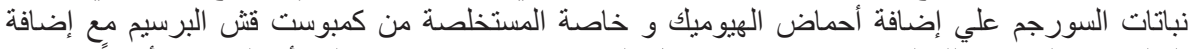

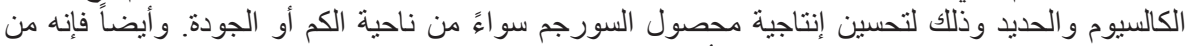

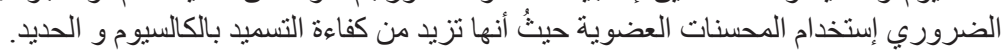

